\title{
OBTAINING LISTENING COMPREHENSION BY USING VIDEO MATERIALS
}

\section{Perolehan Pemahaman Mendengarkan dengan Menggunakan Materi Video}

Justsinta Sindi Alivi*, Suharyono**

*State Islamic University Maulana Malik Ibrahim, Malang

justsinta.sindi@gmail.com

**State University of Malang

ion.suharyono@gmail.com

\begin{abstract}
The utilization of multimedia technology has given positive contributions in the implementation of teaching listening. It provides the teachers with easier and more efficient ways to facilitate listening materials and practices in the form of audio as the main important sources. However, employing audio only is considered to be not enough to assist students to comprehend the information well. The use of audio-visual materials such as videos is proposed as a better means to acquire students' listening comprehension. The visualization of videos provides the students the ease to get better contexts, decrease the boredom, and stimulate imagination to the more authentic situation. This paper employed causal comparative research to examine the use of audio and audio-visual materials in teaching listening, then to evaluate which one has better result in obtaining students' listening comprehension as viewed from genders.

Keywords: video, listening comprehension, gender
\end{abstract}

Teaching listening is one of challenging activities to train students be able to respond, in the other word, be well-comprehend to the information they listen. Many learners of English as Foreign Language (EFL) have considered listening as a difficult skill due to several factors. Brown and Yule (1983b, in Nunan, 1991: 24) mention several factors noticeably becoming the reasons of listening problems. They include speaker factors (the number of speakers, the accent, the speed of speech), roles of listeners (as participant or eavesdropper, the listeners' interest), contents (how far the listeners master grammars, vocabularies, and background knowledge), and also supportive aids (the availability of pictures, diagrams, or other visual aids). The similar factors are also mentioned by Wilson (2008: 12) like characteristics of the messages, deliveries, listeners and environments.

A common way to teach listening is by giving the students auditory materials for the students' practices and tests. However, a better activity to teach skills may in the form of giving the students authentic materials. Gardner and Miller (1999) as cited in Woottipong $(2014,203)$ describe that authentic materials can be in the form of written texts, audio recordings of actual communication, or videos. Although 
audio materials could provide authenticity, however, the materials are possibly still not enough to assist students in comprehending the information. It means that the absence of visual aids could be a challenge in listening comprehension. Thus, providing the students with both audio and visual materials is supposed better to achieve students listening comprehension.

A Video is a form of audio visual materials having been popular to use in teaching language learning, particularly in listening. Many research agree that videos can obtain the students with better comprehension since it presents the more authentic materials for samples in the real-life communication as well as triggers students' motivation due to the existence of pictures that are able to throw students boredom away (Mirvan, 2013) as cited in (Woottipong, 2014; Meskill, 1996; and Cakir, 2006). Furthermore, Herron \& Tomasello (1992, as cited in Woottipong, 2014: 201) contends that video-based instructions in teaching language learning is preferable to use than auditory materials since it offers multiplying modalities enabling the students be encouraged to learn and it appeals more attention to the auditory outputs. Harmer (2007: 308) also asserts that Films or videos allow students to get into a whole ranges of other communication worlds such as seeing how different people stand when they talk to each other (how close they are, for example) or what sort of food people eat. Moreover, Audio-visual materials like videos are more authentic than audio-only since it presents some pictures and gestures that can support students to interpret the meaning of messages and understand the information of video contents (Woottipong, 2014: 210; Potosi, et al, 2009: 32-33).

Nevertheless, the employment of videos as listening materials should be selective according to the students' level of proficiency. Potosi, et al. (2009) argues that the videos should contain current and interesting topics to capture students' interest. Furthermore, he explains that having video containing complex grammatical structures, too fast paces, and advanced idiomatic expressions for students with low proficiency level should be considered as avoidance. In addition, the presence of clear pictures clues and contextual interaction should be also well measured. In this condition, if students with low proficiency level are given videos about presenting speech, they probably still find it difficult to grasp the information. 
Hence, selecting wrong video materials is able to result in the students' confusion even hinder them to reach good interpretation on the information of the video contents. At the end, the students would find the difficulty in listening to the videos just like when they use audio-only materials.

Some studies believe that gender is a viable factor influencing students' achievements. Some results of controversial research were discovered in accordance to several considerations. Naderi, et al. (2009) claim that there is no relation between genders to the academic achievement. O'loughlin (2002, in Karami (2013) found that genders give little effects to the students' IELTS Scores. In the other studies conducted by O'Reilly \& McNamara (2007) as cited in Martinez (2014) may found that males had higher score than females on measures of science knowledge, state science test, and passage comprehension. However, the finding is asserted by Brantmeier (2007) and Yazdanpanah (2007) as cited in Martinez ( 2014), they found that there is no significant relationship between genders and students reading comprehension - dealing with topic familiarity. In spite of this, Brantmeier found that females had better recall than males. Furthermore, Yazdanpanah also found that females significantly had better abilities in handling both types of reading processes (top-down and bottom-up) than males.

As the aforementioned description dealing with the benefits offered by audiovisual materials in obtaining students' listening comprehension, this study try to compare the use of video materials and audio-only materials, and to identify how significant the differences of both types of media in the students' listening comprehension. Furthermore, this study also tries to identify how genders could influence the students' listening comprehension in both materials.

The research problem are; Is there any statistically significant difference between groups of students using videos and groups of students using audio-only in listening comprehension?, Is there any statistically significant difference between female and male students in listening comprehension using videos and audio-only?

The objective of the research is to analyze whether there is statistically significant difference between groups of students using videos and groups of students using audio-only in listening comprehension. And, to identify whether 
there is statistically significant difference between female and male students in listening comprehension using videos and audio-only.

\section{RESEARCH METHOD}

\section{Research Design}

The study used causal comparative design to see how the implementation of video and audio materials could influence students' listening comprehension. Furthermore, the analysis of how genders affect the students' comprehension toward both materials - videos and audio - was also taken. Thus, the study presents descriptive quantitative data from the comparison analysis. The independent variables were video and audio, while the dependent variable was the students' achievement (comprehension) toward each material.

\section{Population and Sample}

The population of the study was $4^{\text {th }}$ semester students of social study department in Islamic State University of Malang academic years 2014-2015. There were three classes in the cohort; however, two classes were taken as the sample. Each class had 31 students. Therefore, 62 subjects were involved as the samples. The classes were chosen based on the similarity of English proficiency level, and it was found that those classes were still at low-intermediate level. Group A was given listening using audio-only materials, and group B was given video materials.

\section{Data Collection}

The instruments used to collect the data were tests using audio materials and tests using video materials. Both groups (group video and group audio) would have the same video materials, yet for audio group was given the audio-played only without displaying the pictures of the videos.

The types of materials were selected adjusting to the level of students' English proficiency. Hence, three videos containing contextual description were prepared as the test-materials which those were administered for testing. Video I describes an issue by showing pictures as the visual clues. Video II presents an interactive conversation in an authentic situation. Video III provides several interviews to some people containing several textual descriptions as the contextual clues. 
Before the students of both groups have listening comprehension tests, the teacher discussed the difficult words the students found in the instructions, and give them time to be fully understand about what the instructions direct to them . It was conducted to avoid the students' misconception about the instruction.

\section{Data Analysis}

The result of the tests then was analyzed using t-test two-sample assuming unequal variance to compare two means in different variances (video and audio). Furthermore, one-way ANOVA was also employed to compare the means of genders in both variables. It consisted of mean of male-audio, female-audio, malevideo, and female-video.

\section{FINDING}

The finding presents the result of data analysis to answer each research question. The first research question about whether there is any statistically significant difference between groups of students using videos and students using audio-only in listening comprehension was analyzed employing t-test two-sample to assume unequal variance in Microsoft excel data analysis. The result is presented in Table 3.1

Table 3.1 result of t-test to see the difference between videos and audio-only materials

\begin{tabular}{lll}
\hline t-Test: Two-Sample Assuming Unequal Variances & \\
\hline & AUDIO & VIDEO \\
Mean & 56.09677419 & 69.16129032 \\
Variance & 126.6903226 & 68.33978495 \\
Observations & 31 & 31 \\
Hypothesized Mean Difference & 0 & \\
Df & 55 & \\
t Stat & -5.208628059 & \\
P(T<=t) one-tail & $1.46615 \mathrm{E}-06$ & \\
t Critical one-tail & 1.673033965 & \\
P(T<=t) two-tail & $2.9323 \mathrm{E}-06$ & \\
t Critical two-tail & 2.004044783 & \\
\hline
\end{tabular}


If $\mathrm{t}$ stat $>\mathrm{t}$ one tail, or $\mathrm{p}$ value (one tail/ two tail) $<$ alpha $(0.05)$, null hypothesis is rejected, and there is significantly different. The $t$ value ( $t$ stat) shows a greater value (5.208) than the critical $t$ value for a one-tailed test (1.673). Furthermore, The $\mathrm{p}$ values one-tailed test (1.46615E-06) is less than alpha (0.05), it can be concluded that null hypothesis is rejected. It means that there is a significantly difference between the use of videos and audio-only materials in students' listening comprehension.

The second research question about whether genders could affect differently in the use of video and audio-only materials in students listening comprehension was analyzed using ANOVA single factor. The result of analysis in Microsoft excel is presented in Table 3.2.

Table 3.2 Effects of Genders

ANOVA: SINGLE FACTOR

\begin{tabular}{|c|c|c|c|c|c|c|}
\hline Groups & Count & Sum & Average & Variance & & \\
\hline M- AUDIO & 13 & 690 & 53.07692 & 114.9103 & & \\
\hline F-AUDIO & 18 & 1049 & 58.27778 & 130.4477 & & \\
\hline M-VIDEO & 18 & 1231 & 68.38889 & 86.60458 & & \\
\hline F-VIDEO & 13 & 913 & 70.23077 & 46.02564 & & \\
\hline \multicolumn{7}{|l|}{ ANOVA } \\
\hline Source of Variation & $S S$ & $d f$ & $M S$ & $F$ & $P$-value & ${ }^{7}$ crit \\
\hline Between Groups & 2875.348 & 3 & 958.4494 & 9.8895 & $2.31423 \mathrm{E}-05$ & 2.763552 \\
\hline Within Groups & 5621.12 & 58 & 96.91586 & & & \\
\hline Total & 8496.468 & 61 & & & & \\
\hline
\end{tabular}

If $\mathrm{F}>$ Fcrit, we reject the null hypothesis. The table shows that $\mathrm{F}$ (9.8895) is greater than Fcrit (2.763552). The $\mathrm{p}$ value also shows lower value (2.31423E-05) than alpha (0.05). It means that there is also a significantly difference between male and female students' comprehension in the use of video and audio-only materials.

\section{DISCUSSION}

The finding shows that there is a significant difference between the employment of videos and audio, in which audio-visual materials presents better mean of scores than audio-only. The result of the study agrees to Herron \& Tomasello (1992) and Woottipong (2014: 201) that videos obtain a better influence 
than audio, However, both means still show low scores, audio (56.09) and videos (69.16). It is assumed that the video level is still difficult for the students' level.

Furthermore, the finding also found that there is a significant difference among genders in the use video and audio material to the students' listening comprehension. However, the result of finding shows that females have greater mean scores than males in both audio and audio-visual materials. It is probably because the females have better recall and comprehending process than males just like what Brantmeier (2007) and Yazdanpanah (2007) that are cited in Martinez (2014) found in their studies. Nevertheless, those factors are not enough yet to justify that female have better listening comprehension performance than males. Other factors such as motivations, learning styles, language masteries, etc. should be also taken as deliberation.

\section{CONCLUSION}

Teaching listening using videos is deemed to offer better comprehension than provide the students with auditory materials only. The availability of images and real-life contexts in the videos could assist the students to be able to infer and interpret the situations and information of the video content. In addition, being more selective in preparing video materials should be fair adjusting to the students' level of proficiency. The last, females probably possess better performances in comprehending listening than males, yet the condition is supposed to be influenced by some intern factors of each individual that one group to another could be different.

\section{REFERENCES}

Cakir, I. 2006. The Use of Audio as an Audio-Visual Material in Foreign Language Teaching Classroom. The Turkish Online Journal of Educational Technology (TOJET) 5 (4), 67- 72.

Harmer, J. 2007. The Practice of English Language Teaching (4 ${ }^{\text {th }}$ Edition). New York: Pearson Education Limited. https:// epositorio.utp.edu.co/dspace/bitstream/11059/1936/1/371333A786.

Karami, H. 2013. An Investigation of Gender Differential Performance on a 
High-Stakes Language Proficiency Test in Iran. Asia Pacific Educ. Rev. 14, 435-449.

Martinez, A.C.L. 2014. Analysis of the Effect of Content Familiarity and Gender on English as a Foreign Language Reading Comprehension by Spanish University Students. Porta Linguarum 21, 69-84.

Naderi, H., Abdullah, R., Aizan, T., and Sharir, J. 2009. Intellegence and Academic Achievement: an Investigation of Gender Differences. Life Science Journal 7(1), 83-87.

Nunan, D. 1991. Language Teaching Methodology. Norwich: Prentice Hall International.

Potosi, L.J.A., Loaiza, E.A.G., and Garcia, A.C.L. 2009. Using Video Materials as a Teaching Strategy for Listening Comprehension.

Wilson, JJ. 2008. How to Teach Listening. Essex: Pearson Education Limited.

Woottipong, K. 2014. Effect of Using Video Materials in the Teaching of Listening Skills for University Students. International Journal of Linguistics 6 (4), 200212. 